Stanisław Adamiak

Papieski Uniwersytet Gregoriański, Rzym

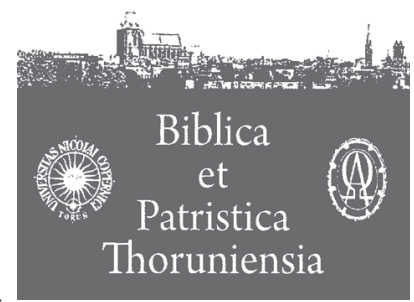

4 (2011) ISSN 1689-5150

\title{
Sześcioksiąg w mozaikach bazyliki Santa Maria Maggiore w Rzymie
}

\section{Hexateuch in the mosaics of Santa Maria Maggiore at Rome}

Słowa kluczowe: sztuka wczesnochrześcijańska, mozaiki, ilustracje biblijne, Bazylika Matki Bożej Większej w Rzymie.

Key words: Early Christian art, mosaics, Bible illustrations, basilica of Santa Maria Maggiore at Rome.

B

azylika większa ${ }^{1}$ Matki Bożej na Eskwilinie, znana powszechnie pod swoją włoską nazwą Santa Maria Maggiore, zajmuje szczególne miejsce wśród bazylik Rzymu. Jest jedną z czterech bazylik papieskich (obok Arcybazyliki Najświętszego Zbawiciela i św. Janów Chrzciciela i Ewangelisty na Lateranie, bazyliki św. Piotra na Watykanie i bazyliki św. Pawła za Murami) i jako taka stanowi jeden z głównych celów pielgrzymek przybywających do Wiecznego Miasta. Podczas gdy pozostałe bazyliki papieskie szczycą się relikwiami Apostołów, pod ołtarzem Santa Maria Maggiore znajdują się tylko relikwie żłóbka z Betlejem (podobno sprowadzone do Rzymu za pontyfikatu Teodora I, papieża pochodzenia palestyńskiego ${ }^{2}$ ), których autentyczność z pewnością może być kwestionowana. Głównym przedmiotem czci w tej bazylice jest za to ikona Matki Bożej Zbawienia Ludu Rzymskiego (Salus Populi Romani). Autorstwo

1 Bazylika pierwotnie nosiła po prostu wezwanie Matki Bożej. Przymiotnik „większa”, dla odróżnienia od innych kościołów poświęconych Maryi, pojawia się w VII-VIII wieku, tak że za papieża Sergiusza II (844-847) „wszyscy nazywali ją większą (maior)” (Liber pontificalis, wyd. L. Duchesne, Paris 1955, II, 91).

2 E. Venier, Santa Maria Maggiore: la Betlemme di Roma, Roma 1999, 24. Od tego czasu wzmianki o bazylice Matki Bożej ad Praesepem pojawiają się też w Liber Pontificalis. 
tej ikony, Czarnej Madonny podobnej do tych z Bolonii i Jasnej Góry, przypisuje się św. Łukaszowi Ewangeliście.

Santa Maria Maggiore zachowała swój oryginalny, późnostarożytny charakter najlepiej ze wszystkich wielkich bazylik Rzymu. Obecna bazylika św. Piotra została wzniesiona w XVI wieku, bazylikę św. Pawła za Murami odbudowano od podstaw po wielkim pożarze w 1823 roku, a bazylikę lateraneńską poddawano przez wieki tylu przeróbkom i odnowom, że trudno w niej odnaleźć oryginalnego ducha budowli. Tymczasem konstrukcja Santa Maria Maggiore, mimo rozlicznych upiększeń i dodatków, pozostała niezmieniona przez ponad tysiąc pięćset lat - to jest wciąż ten sam budynek, te same mury i kolumny. Wchodząc do Santa Maria Maggiore, wchodzimy więc do bazyliki z piątego wieku, ukończonej za papieża Sykstusa III (432-440) po soborze efeskim (431 - sobór ten ogłosił dogmat o Bożym macierzyństwie Maryi), w okolicach bazyliki wzniesionej niecałe sto lat wcześniej przez papieża Liberiusza (352-366) - stąd funkcjonujące do dziś określenie „basilica Liberiana” i święto poświęcenia bazyliki 5 sierpnia, zwane „Matką Bożą Śnieżną” (według legendy Liberiusz podjął decyzję o budowie bazyliki w miejscu, w którym w sierpniu spadł śnieg) ${ }^{3}$.

Wzrok wchodzącego do bazyliki instynktownie kieruje się ku imponującym mozaikom znajdującym się w jej przedniej części: w apsydzie i na łuku triumfalnym. Kiedy podziwia się umieszczone na łuku triumfalnym wspaniałe przedstawienie scen z dzieciństwa Jezusa i znajdujące się za nimi dekoracje odwołujące się do Apokalipsy, łatwo przeoczyć jeszcze jeden cykl mozaik, znajdujący się na górze bocznych ścian nawy głównej. Tymczasem jest to cykl zupełnie niepowtarzalny i wyjątkowy. Podobnie jak mozaiki łuku triumfalnego, mozaiki na ścianach bocznych są współczesne konstrukcji bazyliki i stanowią pierwsze tak dobrze zachowane cykle ilustracyjne sztuki chrześcijańskiej ${ }^{4} \mathrm{O}$ ile jednak mozaiki z łuku triumfalnego opierają się na Ewangeliach (zarówno kanonicznych, jak i apokryficznych), o tyle mozaiki z nawy głównej przedstawiają ilustracje do sześciu pierwszych ksiąg Starego Testamentu.

Niestety, przebudowy bazyliki, zwłaszcza konstrukcja kaplic bocznych, spowodowały, że nie wszystkie mozaiki zachowały się do naszych czasów. Z 42 oryginalnych mozaik (pod każdym z okien) zachowało się 27. Co dokład-

3 Liber Pontificalis, I, 208.232. Bazyliki liberiańskiej do dziś nie udało się odnaleźć, nie przeprowadzono jednak pełnych wykopalisk pod istniejącą bazyliką Santa Maria Maggiore (V. Saxer, Sainte-Marie-Majeure: une basilique de Rome dans l'histoire de la ville et de son église (Ve-XIIIe siècle), Rome 2001, 27-29).

4 Na datowanie mozaik łuku wskazuje umieszczona tam inskrypcja dedykacyjna Sykstusa III. O współczesności mozaik łuku i nawy będzie mowa później. 
nie można więc zobaczyć dzisiaj w nawie głównej Santa Maria Maggiore ${ }^{5} \mathrm{Na}$ ścianie zachodniej znajdują się następujące sceny:

1. Ofiara Melchizedeka - Melchizedek ofiaruje chleb i wino, Abraham nadjeżdża na czele żołnierzy, na obłokach ukazuje się Chrystus (Rdz 14,17$-20)$.

2. Gościnność Abrahama, ujęta w trzech scenach - część górna panelu: Abraham wita trzech aniołów (przedstawieni są jednakowo, każdy w aureoli, dodatkowo nimb otacza całą środkową postać); część dolna panelu: po lewej stronie Sara na polecenie Abrahama przygotowuje trzy podpłomyki, po prawej stronie Abraham podaje je aniołom ( $\mathrm{Rdz} 18,2-8)$.

3. Rozdzielenie się Abrahama i Lota - większą część panelu zajmuje rozdzielenie się dwóch grup: Abrahama, Sary, Izaaka i ich służby po jednej, a Lota z żoną, córkami i służbą po drugiej stronie; na dole przedstawionych jest dwóch pasterzy i pewna liczba zwierząt domowych - jest to z pewnością odniesienie do biblijnego opisu zatłoczenia pastwisk (Rdz 13,5-11).

4. Mozaika nie zachowała się.

5. Mozaika nie zachowała się.

5. Mozaika nie zachowata się.

6. Izaak błogosławi Jakuba - góra panelu przedstawia Izaaka leżącego na łożu i błogosławiącego Jakuba, który ma rękę osłoniętą sierścią. Przygląda się temu Rebeka. Dół panelu jest w większości zniszczony, ale widać na nim Izaaka, który według wszelkiego prawdopodobieństwa rozmawia z Ezawem (Rdz 27,14-30).

7. Mozaika nie zachowała się; obecnie barokowa mozaika przedstawia sen Jakuba, która to scena w tym miejscu wydaje się być prawdopodobna.

8. Na górze panelu przedstawiony jest powrót Racheli do domu - za nią idą owce i pasterze, w drzwiach domu czekają na nią Jakub i Lea. Na dole

5 Pełen opis mozaik znajduje się w: J. Wilpert, Die Römischen Mosaiken und Malereien der kirchlichen Bauten vom IV. bis XII. Jahrhundert, Freiburg im Br. 1917, I/1, 423-473. O pół wieku późniejsze są wydania z dobrymi, kolorowymi ilustracjami: C. Cecchelli, I mosaici della basilica di S. Maria Maggiore, Torino 1956 i H. Karpp, Die frühchristlichen und mittelalterlichen Mosaiken in Santa Maria Maggiore zu Rom, Baden-Baden 1966. Dwie najlepsze monografie, szczegółowo analizujące program ikonograficzny i poszczególne sceny, zostały także napisane, niezależnie od siebie, w latach siedemdziesiątych: B. Brenk, Die frühchristlichen Mosaiken in S. Maria Maggiore zu Rom, Wiesbaden 1975 i J.G. Deckers, Der alttestamentliche Zyklus von S. Maria Maggiore. Studien zur Bildgeschichte, Bonn 1976. Później mozaiki były analizowane w dziełach poświęconych całej bazylice: F. Gandolfo, $\mathrm{La}$ basilica sistina: i mosaici della navata e dellarco trionfale, w: Santa Maria Maggiore a Roma, red. C. Pietrangeli, Firenze 1988, 85-123 i L. Sperduti, La Basilica paleocristiana, w: Santa Maria Maggiore a Roma, red. R. Luciani, Roma 1996, 49-72 oraz V. Saxer, 42-54. 
panelu z lewej strony Laban wita Jakuba, z prawej prowadzi go do domu. W drzwiach domu czeka na nich Rachela, podczas gdy samotna Lea przygląda się całej scenie z lewej strony (Rdz 29,12-14).

9. Jakub prosi o rękę Racheli: po prawej stronie stoi Jakub wskazujący ręką w stronę centrum kompozycji, gdzie znajduje się Laban ze swoimi obiema córkami. Laban wskazuje ręką w prawo, gdzie widać owce, które Jakub będzie musiał paść przez siedem lat; dół panelu nie zachował się ( $\mathrm{Rdz}$ 29,15-20).

10. Góra panelu: Jakub powraca z pastwiska, by poskarżyć się Labanowi, że dostał za żonę Leę, a nie Rachelę; obie córki Labana stoją z nim przed domem. Dół panelu: z prawej strony zawarcie małżeństwa przez Jakuba i Rachelę, po lewej stronie scena nie do końca zidentyfikowana - przypuszczalnie Laban sprasza sąsiadów na wesele (Rdz 29,21-29).

11. Góra panelu: Jakub umawia się z Labanem o zapłatę za swoją służbę; każdemu z nich towarzyszą pasterze i owce. Dół panelu: w centrum Laban z jednym ze swoich synów, wokół nich pasterze oddzielają cętkowane i pstre kozy oraz czarne owce ( $R d z$ 30,25-36).

12. Góra panelu: $z$ lewej strony Jakub i jego pasterze czuwają nad wodą $z$ gałązkami w prążki w ręku, podczas gdy ich trzody się rozmnażają (Rdz 30, 37-39), z prawej strony Bóg ukazuje się z chmury i każe Jakubowi wyruszyć do Ziemi Kanaan. Dół panelu: Jakub przekazuje tę wiadomość swoim żonom; Lei towarzyszy dwóch synów, Racheli - jeden, Józef (Rdz $31,2-16)$.

13. Mozaika nie zachowała się: obecnie jest w tym miejscu przedstawienie Jakuba rozpoznającego zakrwawione szaty Józefa (Rdz 37,31-35) - zdecydowanie poza kolejnością.

14. Góra panelu: po lewej stronie Ezaw przyjmuje posłów Jakuba, po prawej - posłowie opowiadają o swoim poselstwie Jakubowi, któremu towarzyszą jego żony. Dół panelu nie zachował się, widać tylko w jego lewym górnym rogu dużą grupę żołnierzy z lancami, lecz trudno się domyślać, co mieliby przedstawiać, być może Ezawa ruszającego na spotkanie Jakuba (Rdz 32,4-8).

15. Mozaika nie zachowała się: obecnie jest $w$ tym miejscu, poza kolejnościa, Abraham ofiarujacy Bogu Izaaka (Rdz 22,1-13).

16. Góra panelu: scena niejasna, przedstawia z lewej strony grupę mieszkańców przed ich miastem, z prawej dwóch $\mathrm{z}$ nich kłaniających się przed Jakubem, który siedzi w otoczeniu synów; być może chodzi o układy o kupno ziemi koło Sychem (Rdz 33,18-19). Dół panelu: dwóch synów Jakuba, Symeon i Lewi, mówi mu o zgwałceniu ich siostry Diny (Rdz 34,5-7). 
17. Góra panelu: Symeon i Lewi (na lewo od nich siedzi Jakub) układają się z Sychemitami, którym przewodzi Sychem i jego ojciec Chamor (Rdz 34,13-17). Dół panelu: Sychem i Chamor przemawiają do licznej grupy swoich ziomków, nakłaniając ich do przyjęcia warunków synów Jakuba czyli obrzezania się. (Rdz 34,20-23)

18. Mozaika nie zachowała się - obecnie sa w tym miejscu: narodziny Beniamina, śmierć Racheli i jej pochówek koło Betlejem (Rdz 35, 16-20); może to odzwierciedlać mozaikę oryginalną.

19. Mozaika nie zachowała się - obecnie: Daniel w jaskini lwów (!).

20. Mozaika nie zachowała się - obecnie: przybycie Jakuba i jego synów do Egiptu $(R d z 46,6)$ oraz walka Jakuba $z$ aniołem ( $R d z$ 32,25-30).

$\mathrm{Na}$ ścianie wschodniej:

22. Mozaika nie zachowała się

23. Góra panelu: młody Mojżesz przed córką faraona, która siedzi na tronie; w tle pięć dam dworu (Wj 2,10). Dół panelu: młody Mojżesz wśród filozofów egipskich, zasiadających w niewielkim amfiteatrze.

24. Góra panelu: ślub Mojżesza i Sefory, w centrum między młodymi kapłan Jetro, z obu stron liczni świadkowie (Wj 2,21). Dół panelu: scena bukoliczna, Mojżesz i dwaj inni pasterze pilnują owiec; Mojżesz wpatruje się w chmurę, niektórzy widzą wyłaniającą się z niej rękę Bożą - w każdym razie scena ta jest $\mathrm{z}$ reguły interpretowana jako powołanie Mojżesza (Wj 3,1).

Trzy następne mozaiki zostały zniszczone w XVI wieku podczas budowy kaplicy sykstyńskiej, ale zachowały się ich rysunki (watykański Codex Barberini Lat. 4405), dzięki którym wiemy, jakie sceny były tam przedstawione:

25. Spotkanie Mojżesza i Aarona (Wj 4,27). Mojżesz i Aaron przed faraonem (Wj 5,1-4).

26. Polecenie Paschy całemu ludowi Izraela (Wj 12,3-4). Obietnica Ziemi Obiecanej - Mojżesz wskazuje ludowi na miasta i drzewa (?)(Wj 13,5).

27. Ogłoszenie Paschy przez Mojżesza starszym Izraela. Złożenie w ofierze baranka paschalnego (Wj 12, 21-27).

28. Przejście przez Morze Czerwone, a właściwie klęska faraona i zatopienie jego armii (Wj 14,26-31).

29. Góra panelu: po lewej stronie duża grupa Izraelitów dyskutuje z Mojżeszem; po prawej stronie Mojżesz zwraca się do Boga, który ukazuje się na chmurze. Dół panelu: po prawej stronie stoją Mojżesz, Aaron i Chur, a po lewej Izraelici zbierają spadające z nieba przepiórki (Wj 16,1-4.13).

30. Góra panelu: Wody Mara - z lewej strony Izraelici wskazują Mojżeszowi na wodę, której nie można pić, z prawej strony Mojżesz, na polecenie Boga (widocznego na chmurze w prawym górnym rogu mozaiki) wkłada 
drewno do wody, a ci sami Izraelici piją ją łapczywie Wj 15,23-25). Dół panelu: z prawej strony Mojżesz z dwoma towarzyszami, z lewej miasto; wódz żołnierzy, którzy wyszli przed miasto, wyciąga rękę przeciw Izraelitom - scena różnie interpretowana jako wrogość Amalekitów (Wj 17,8), albo wrogość Edomu (Lb 20,14-21) ${ }^{7}$ - pierwsza interpretacja logiczniejsza w kontekście sceny następnej. $Z$ kolei Deckers ${ }^{8}$ interpretuje ten obraz jako rozmowę Mojżesza $\mathrm{z}$ Jozuem przed bitwą z Amalekitami (Wj 17,9-10).

31. Bitwa z Amalekitami - Mojżesz modli się na górze w otoczeniu Aarona i Chura (ale ręce wyciąga jeszcze sam, bez pomocy z ich strony) (Wj $17,10-13)$

32. Góra panelu: zwiadowcy wracają z ziemi Kanaan, Mojżesz i Aaron stoją przed przybytkiem (Lb 13, 26-31) ${ }^{9}$. Dół panelu: zbuntowani Izraelici rzucają kamieniami w Mojżesza, Jozuego i Kaleba, którzy uciekają w stronę przybytku; tam są osłonięci mandorlą - swoistą sferą, rozciągniętą przez wychylającą się z obłoków rękę Boga (Lb 14,10).

33. Góra panelu: $\mathrm{z}$ lewej strony Mojżesz, z księgą Prawa w ręku, wydaje ostatnie polecenia stojącym przed nim Izraelitom; z prawej strony Mojżesz umiera, leżąc samotnie na górze (Pwt 31,28-30; 34,1-5). Dół panelu: czterech lewitów niesie Arkę Przymierza, przed nimi i za nimi kroczy po trzech kapłanów.

34. Góra panelu: Izraelici przechodzą przez Jordan (Joz 3,14-17). Dół panelu: Jozue (otoczony żołnierzami) wysyła dwóch zwiadowców do Jerycha, widocznego po prawej stronie (Joz 2,1).

35. Góra panelu: Jozue, na czele wojska, kłania się Wodzowi Zastępów Pańskich, stojącemu z włócznią w ręku (nie mieczem, jak w tekście biblijnym), z aureolą na głowie (Joz 5,13-15). Dół panelu: po prawej stronie zwiadowcy uciekają z Jerycha (jeden już jest na ziemi, drugi jest spuszczany z muru przez Rachab), po lewej stronie meldują się Jozuemu (Joz 2,21-24).

36. Zdobycie Jerycha: chronologicznie pierwszy jest dół panelu, w centrum którego znajduje się niesiona przez kapłanów Arka Przymierza; dokoła niej inni kapłani dmą w trąby, Jozue z wojskiem się temu przygląda (Joz

6 B. Brenk, dz. cyt., 90.

7 Np. J. P. Richter, A. Cameron Taylor, The Golden Age of Classical Christian Art, London 1904, 190-193.

8 J. G. Deckers, dz. cyt., 192.

9 B. Brenk (dz. cyt., 91) widzi tu spór ze zgrają Koracha (Wj 16). 
6, 8-14). Góra panelu: w centrum Jerycho, z obu stron Izraelici, z lewej strony mur się przewraca; na murach Jerycha stoi Rachab (Joz 6,20-21).

37. Góra panelu, przedstawiająca $\mathrm{z}$ lewej strony zdobywanie miasta, a z prawej żołnierzy biegnących do Jozuego, różnie interpretowana: albo zdobycie $\mathrm{Aj}$ (po początkowej porażce pierwszych trzech tysięcy Izraelitów, o której posłańcy donoszą Jozuemu - Joz 7,4-5) ${ }^{10}$, albo oblężenie Gibeonu przez królów amoryckich i poselstwo o pomoc do Jozuego (Joz 10, 6). Dół panelu: z lewej strony Bóg przemawia do Jozuego, z prawej Jozue, konno, wyrusza na czele wojska.

38. Góra panelu: klęska Amorytów, Jozue na koniu tratuje przeciwników. Dół panelu: Izraelici przyglądają się, jak na uciekających Amorytów spadają kamienie, zrzucane przez rękę Boga (Joz 10,10-11).

39. Jozue, stojący na pagórku, gestem prawej ręki zatrzymuje słońce i księżyc; po jego obu stronach dwa wojska gotowe do walki (Joz 10,12-13).

40. Góra panelu: Przed oblicze Jozuego, stojącego pośrodku, przyprowadzani są pojmani królowie kananejscy. Dół panelu jest w dużej mierze zniszczony, po lewej stronie widać Jozuego, przemawiającego w otoczeniu straży (Joz 10,22-27).

Oczywistym jest, że dobór tematów do mozaik zdobiących nawę nie był przypadkowy. Zarówno po lewej, jak i po prawej stronie nawy, mozaiki układają się w logiczny cykl narracyjny. Jest on konsekwentnie podzielony na dwie części: lewa ilustruje historie z Księgi Rodzaju, a prawa historie wyjścia z Egiptu i zdobycia Ziemi Obiecanej, opisane w następnych księgach Starego Testamentu. Trzeba sobie natomiast zadać pytanie, czy mozaiki nawy są w jakiś sposób związane z mozaikami łuku triumfalnego, przedstawiającymi historie dzieciństwa Jezusa. Po lewej stronie łuku znajduje się (od góry): Zwiastowanie, Pokłon Magów, Rzeź Niewiniątek i owce wchodzące do Jeruzalem, po prawej zaś: Ofiarowanie w Świątyni, Ucieczka do Egiptu (dokładniej apokryficzna scena przybycia Świętej Rodziny do Sohennen i hołdu Afrodyzjusza ${ }^{11}$ ), przybycie Magów do Heroda i owce wchodzące do Betlejem ${ }^{12}$.

10 Np. C. Cecchelli, dz. cyt., 181-182; J. Kollwitz, Der Josuazyklus von S. Maria Maggiore, „Römische Quartalschrift” 61 (1966), 105-110, 107.

11 Ewangelia Pseudo-Mateusza, 22-24 (wyd. M. Starowieyski, Apokryfy Nowego Testamentu, t. I/1, Kraków 2003).

12 Powszechnie przyjęta interpretacja scen $\mathrm{z}$ łuku triumfalnego wiąże się z pewnymi trudnościami w zrozumieniu znaczenia niektórych postaci. Suzanne Smith podjęła próbę alternatywnego odczytania łuku, w jeszcze większej harmonii z mozaikami nawy: zamiast sceny z Afrodyzjuszem widzi spotkanie Jezusa, Dawida i Izajasza, zamiast Zwiastowania Maryi i Józefowi - obietnicę przekazaną Sarze i Abrahamowi itd. Te daleko idące inter- 
Na pierwszy rzut oka mogłoby się wydawać, że między dwoma kompleksami mozaik nie ma bliższego związku. To wrażenie jest tym silniejsze, że narracja cyklów nawy „ucieka” od łuku, zamiast się do niego zbliżać - po obu stronach pierwszy obraz cyklu znajduje się przy łuku, ostatni przy wejściu do bazyliki. Jednak kiedy się przyjrzeć dokładnie pierwszym scenom z każdej strony, widać wyraźnie, że ich wybór nie był przypadkowy - i że był on związany $\mathrm{z}$ tematyką łuku ${ }^{13}$.

Charakterystyczny jest wybór scen, które otwierają cykl mozaik opartych na Księdze Rodzaju. Według chronologii, pierwszą z nich powinno być rozdzielenie się Abrama i Lota - ta scena nie była jednak w starożytności (ani później) specjalnie komentowana, nie znaleziono też dla niej żadnego powszechnie uznanego sensu typicznego. Tymczasem w Santa Maria Maggiore rozdzielenie się Abrama i Lota jest dopiero trzecią mozaiką - dwa pierwsze miejsca, najbliższe prezbiterium, są zajęte przez sceny chronologicznie późniejsze, ale za to niezwykle często interpretowane w sensie typicznym: Ofiarę Melchizedeka i Gościnność Abrahama. Pierwsza z tych scen, najbliższa ołtarzowi, jest też w oczywisty sposób odnoszona do Eucharystii, podczas gdy druga wskazuje na tajemnicę Wcielenia, zarówno poprzez ukazania trzech aniołów (typu Trójcy Świętej), jak i przez obecność Sary, która słyszy w tym momencie zapowiedź narodzin Izaaka (typu Chrystusa).

Z kolei po stronie wschodniej pierwsza mozaika nie zachowała się, ale druga - Mojżesz u córki faraona i dysputa Mojżesza z filozofami - wskazuje wyraźnie na związek cyklu starotestamentalnego z dzieciństwem Jezusa. Mojżesz, uratowany $\mathrm{z}$ rzezi dzieci hebrajskich $\mathrm{w}$ Egipcie (zdaniem Sperdutiego prawie na pewno przedstawionej na pierwszej - niezachowanej - mozaice $z$ tej strony nawy ${ }^{14}$ ) i wychowywany przez córkę faraona jest typem Jezusa uratowanego z rzezi niewiniątek w Betlejem (ukazanej po lewej stronie łuku triumfalnego), podczas gdy scena dysputy młodego Mojżesza z filozofami egipskimi odnosi się nie tyle do Księgi Wyjścia, gdzie jej w ogóle nie znajdujemy (źródłem może być co prawda $\mathrm{Dz} 7,22$, mówiący o „wychowaniu Mojżesza we wszystkich mądrościach egipskich”, prawdopodobniejsze jest jednak odwołanie się do „Ży-

pretacje wydają mi się jednak niedostatecznie uzasadnione i mało prawdopodobne (zob. S. Smith, "The Promissed Blessing»: The Iconography of the Mosaics of S. Maria Maggiore, „The Art Bulletin” 61 (1979), 518-540).

13 Na wspólną genezę obu cykli wskazuje też ich jednakowy charakter artystyczny por. A. V. Byvanck, Das Problem der Mosaiken von Santa Maria Maggiore, w: Festschrift Hans R. Hahnloser, Basel 1961, 15-26, 16; J. G. Deckers podkreśla jednak różnice stylu (dz. cyt., 281).

14 L. Sperduti, dz. cyt. 70. 
wotu Mojżesza" Filona z Aleksandrii ${ }^{15}$ ), co do odnalezienia dwunastoletniego Jezusa w świątyni (Łk 2). Ilustracji do tego epizodu Ewangelii nie znajdujemy co prawda na łuku triumfalnym, ale umieszczona po jego prawej stronie scena przybycia Świętej Rodziny do Egiptu przypomina raz jeszcze o typologii Mojżesz-Jezus.

W mozaikach łuku triumfalnego drugą najważniejszą osobą po Jezusie jest jego Matka. Maryja zajmuje centralną pozycję w scenach Zwiastowania i Pokłonu Magów (z lewej strony), jest też wyraźnie widoczna w scenach Ofiarowania i przybycia do Egiptu (z prawej strony). Ale tak jak starotestamentalnym typem Jezusa jest Mojżesz, obecny w wielu mozaikach po prawej stronie nawy, tak samo typem Maryi są postaci kobiece Starego Testamentu, zwłaszcza żony patriarchów, wszystkie ukazane w mozaikach po lewej stronie nawy. Wyróżnia się wśród nich Rachela, ukazana sześć razy (na mozaikach zachowanych). Samo przedstawianie żon patriarchów przypomina o obietnicy Boga, że Abraham ma się stać ojcem wielu narodów. Pamiętajmy o drugiej scenie cyklu, gdzie widzimy Sarę podczas wizyty trzech aniołów u Abrahama. Od Sary i Rebeki wywodzą się wszyscy Izraelici, a więc także Jezus. Rachela nie wchodzi właściwie w skład genealogii Jezusa (Juda był synem Lei), ale u Jeremiasza jest przedstawiana jako matka całego Izraela (Jr 31,15), a przez to jej osoba jest bezpośrednio połączona w Ewangelii św. Mateusza z rzezią niewiniątek (Mt 2,18). To nie jedyny związek Racheli z tematyką łuku triumfalnego - warto przypomnieć, że została ona pochowana niedaleko od Betlejem, co ukazane jest na jednej z mozaik nowożytnych, przypuszczalnie jednak odtwarzającej tematykę oryginału.

Postaci Rebeki i Lei przypominają o głównym temacie Księgi Rodzaju: Bożym wyborze i obietnicy oraz pytaniu, kto ją będzie dziedziczył. Widać to wyraźnie w trzeciej scenie cyklu, przedstawiającej - jak już wspomnieliśmy, wbrew chronologii - rozdzielenie się Abrama i Lota. U boku Abrama widać tam młodego Izaaka, którego w tym momencie nie było jeszcze na świecie jeśli podążamy za narracją biblijną; w cyklu mozaik Santa Maria Maggiore poprzednią sceną jest jednak Gościnność Abrahama, obecność Izaaka w scenie następnej jest więc już w tym układzie logiczna. Abraham i Lot stanowią pierwszą z par „wybrany-odrzucony” w Santa Maria Maggiore. W scenie rozstania Abrahamowi towarzyszy Izaak, który poniesie dalej obietnicę daną przez Boga jego ojcu; przy Locie natomiast widzimy jego dwie córki, które doprowadzą go do kazirodztwa i zapoczątkowania Moabitów i Ammonitów. Nie wiemy, czy na następnych, zniszczonych panelach nie znajdowała się jeszcze jakaś scena przedstawiająca klasyczną antytezę Sara-Hagar (Ga 4,21-26). Dalej natomiast

15 Filon z Aleksandrii, Żywot Mojżesza, I, 21-22. 
mamy przeciwstawienie Jakuba i Ezawa oraz Racheli i Lei. Jakub jest typem Nowego Ludu Wybranego, bo choć urodzony jako drugi, uzyskał prawa pierworodnego i ojcowskie błogosławieństwo ${ }^{16}$. Podobna jest symbolika Racheli jako Kościoła - poślubiona jako druga, ale bardziej niż Lea ukochana przez Jakuba ${ }^{17}$.

Postaci występujące w mozaikach Santa Maria Maggiore ubrane są w stroje rzymskie, prezentują też gesty i postawy znane ze sztuki klasycznej ${ }^{18}$. Na łuku triumfalnym, w scenie Zwiastowania, Maryja ubrana jest w strój patrycjuszki z czasów późnorzymskich. Aniołowie przywdziewają tuniki i pallia (płaszcze). Podobnie ubrani są aniołowie w scenie Gościnności Abrahama, ale potem również np. sam Abraham, Lot, Laban i Jakub. Z kolei w scenie zaślubin Mojżesza i Sefory zarówno sam Mojżesz, jak i towarzyszący mu mężczyźni, mają na sobie rzymskie togi, a sama scena zachowuje znany z rzymskich sarkofagów schemat dextrarum iunctio - podania prawych rąk na znak zgody: kontrahenci, w tym przypadku nowożeńcy, podają sobie dłonie, czemu przygląda się gwarant umowy (tu: kapłan Jetro). Podobnie przedstawiona jest scena zaślubin Jakuba z Rachelą, aczkolwiek tutaj patriarcha nie jest ubrany w togę.

Sceny zawierania małżeństwa nie są jedynymi, w których mozaiki podążają za klasyczną ikonografią rzymską. Scena powrotu Racheli do domu z pastwiska i jej powitanie przez Labana, tak jak i inne sceny odnoszące się do historii Jakuba i Racheli, czerpią z repertorium klasycznych wyobrażeń bukoliczno-pasterskich: np. towarzyszący Racheli pasterze ubrani są w byrrusy - rodzaj ciepłego okrycia popularnego w północnych prowincjach Cesarstwa. Ikonografia zmienia się wraz z powrotem Jakuba do ziemi Kanaan. Przyjmujący jego wysłanników Ezaw przedstawiony jest jak cesarz, przyjmujący posłów u bram miasta: otoczony uzbrojoną strażą, na głowie ma diadem, okryty jest chlamidą koloru ciemnoniebieskiego, stanowiącego tu odpowiednik cesarskiej purpury ${ }^{19}$. Nie jest to jedyna scena, w której bohaterowie biblijni upodobniają się do rzymskich wodzów - pojawienie się Abrahama przed Melchizedekiem przypomina klasyczny adventus - powrót zwycięskiego wodza na czele wojska. Sama postawa patriarchy - prawa ręka wyciągnięta w geście powitania - przypomina słynny konny posąg Marka Aureliusza z Kapitolu.

16 Św. Augustyn, Objaśnienia psalmów, 46, 6; 136, 18.

17 Św. Justyn, Dialog z Żydem Tryfonem, 134: „Lea to wasz lud i Synagoga, Rachela to nasz Kościół”.

18 Za konsultację i cenne uwagi dziękuję mgr Agnieszce Schreiber z Instytutu Archeologii UMK.

19 B. Brenk, dz. cyt., 73. 
Skoro autorom mozaik udało się wpleść tak dużo aluzji do rzeczywistości rzymskiej w ilustracje „kameralnej” historii patriarchów z Księgi Rodzaju, to tym łatwiej było im nawiązać do klasycznej ikonografii w ilustracjach do historii wyjścia z Egiptu i zdobycia Ziemi Obiecanej. Twórcy cyklu z Santa Maria Maggiore świadomie podkreślili jeszcze militarny charakter tego opowiadania, omijając szereg epizodów dotyczących spraw kultycznych (np. budowę przybytku, inwestyturę kapłanów), a koncentrując się na wydarzeniach wojennych: przedstawia je dziesięć na osiemnaście zachowanych paneli. Dzięki temu przedstawiona na wschodniej ścianie bazyliki historia biblijna mogła przypominać współczesnym wielkie dzieła sławiące zwycięstwa oręża rzymskiego, takie jak choćby słynne kolumny Trajana i Marka Aureliusza.

Mozaiki po prawej stronie Santa Maria Maggiore przedstawiają często sceny zbiorowe, z wielką liczbą uczestników. Arcydziełem jest obraz przejścia przez Morze Czerwone, gdzie po jednej stronie widzimy tłum Izraelitów, natomiast wojsko faraona (konnica i rydwany) częściowo znajduje się na drugim brzegu, a częściowo już w wodzie, albo raczej pod wodą - na powierzchni unoszą się tylko porzucone tarcze. Sam faraon jest centralną postacią mozaiki - tonąc, usiłuje się jeszcze zasłonić tarczą przed gniewem Bożym. Podobnie też bardzo wiele postaci występuje w innych scenach batalistycznych - walce z Amalekitami, Amorytami i zdobyciu Jerycha. Izraelici są generalnie uzbrojeni i ubrani na wzór żołnierzy rzymskich. Wyróżniającą się osobą jest oczywiście Jozue, przedstawiany w stroju wodza rzymskiego. W scenie bitwy z Amorytami pokazany jest $\mathrm{w}$ sposób przypominający nawet obraz Aleksandra Wielkiego pod Issos (zachowany na słynnej mozaice z Pompei, obecnie w Muzeum Archeologicznym w Neapolu). Jozue jest też przedstawiany w bardzo popularnej w sztuce rzymskiej konwencji adlocutio - wodza przemawiającego do żołnierzy, z uniesioną prawą ręką. Widzimy go takim w scenie powrotu zwiadowców z Jerycha i przyjmującego posłańców z Gibeonu. Z kolei wymarsz Izraelitów w stronę Ziemi Obiecanej po śmierci Mojżesza i procesja dookoła Jerycha przypominają sceny rzymskiej procesji triumfalnej, z trębaczami i z Arką Przymierza niesioną na ferculum (rodzaj platformy, na której podczas triumfu prezentowano łupy, widocznej np. na Łuku Tytusa i na fryzie ze świątyni Apollona Sosianusa, obecnie w Museo Centrale Montmartini w Rzymie).

Jaki program teologiczny kryje się więc za doborem treści mozaik w nawie bazyliki Santa Maria Maggiore? Nie próbują one pokazać całej historii Zbawienia, nie zawierają scen z pierwszych rozdziałów Księgi Rodzaju (trzeba tu zauważyć, że treść ta nie była z zasady obca sztuce wczesnochrześcijańskiej tematy takie jak stworzenie Adama i Ewy albo Arka Noego odnajdujemy często na sarkofagach $\mathrm{z}$ tamtej epoki). Omawiane mozaiki nie przedstawiają grzechu i zbawienia - nie ma na nich tak charakterystycznych epizodów jak kult złote- 
go cielca czy wywyższenie węża na pustyni. Znajdujemy za to cały szereg scen niezwykle rzadkich w chrześcijańskiej ikonografii: służba Jakuba u Labana, rozdzielanie ich stad, egzekucja królów amoryckich. Wspominaliśmy już też o niezwykle „batalistycznym” charakterze cyklu Mojżesza i Jozuego.

Uważna analiza mozaik nawy prowadzi do wniosku, że kluczem do nich może być inskrypcja dedykacyjna z łuku triumfalnego: „XYSTUS EPISCOPUS PLEBI DEI" (Biskup Sykstus Ludowi Bożemu). Bazylika została ofiarowana przez papieża Ludowi Bożemu. Wierni, którzy się w niej gromadzili, byli chrześcijanami, ale równocześnie byli rzymianami, doskonale świadomymi tysiącletniej historii swojego miasta. Kilkadziesiąt lat przed konsekracją bazyliki, w 410 roku, nieprzyjaciele (Wizygoci pod wodzą Alaryka) wkroczyli do Rzymu, po raz pierwszy od 390 roku przed Chrystusem. Od samego początku chrześcijaństwo było w Rzymie atakowane jako religia nowa i obca. Teraz doszedł trzeci zarzut: chrześcijaństwo było nieskuteczne, Bóg chrześcijan nie potrafił obronić Wiecznego Miasta tak, jak przez stulecia czynili to starzy bogowie.

Cykl mozaik z Santa Maria Maggiore może stanowić odpowiedź na wszystkie te zarzuty. Po pierwsze, chrześcijanie jako Lud Boży nie stanowią zupełnie nowej rzeczywistości, rozpoczętej czterysta lat temu, lecz są spadkobiercami tradycji Ludu Bożego Starego Przymierza, a te sięgają dużo dalej nawet niż tradycje rzymskie - zauważmy, że wszystkie wydarzenia przedstawione w nawie Santa Maria Maggiore miały miejsce setki lat przed założeniem Miasta.

Zarzut obcości tradycji judeochrześcijańskiej wobec świata rzymskiego był trudniejszy do odparcia. Twórcy mozaik poradzili sobie z nim przenosząc świat biblijny w realia rzymskie, ubierając ojców Izraela w tuniki, togi i rzymskie zbroje, każąc im wykonywać gesty generałów i cesarzy. Abraham czy Jozue pokazani w ten sposób nie byli już postaciami z innego kręgu kulturowego - stawali się bliscy niczym Scypion, Katon lub Juliusz Cezar. Jedyne postaci, które są na mozaikach Santa Maria Maggiore przedstawione jako zdecydowanie egzotyczne, to magowie na łuku triumfalnym, ubrani tak, jak tradycyjnie Rzymianie wyobrażali sobie Persów. Ten obraz, przez kontrast, tylko podkreśla „rzymskość" pozostałych bohaterów mozaik.

Ale czy Bóg chrześcijański, który nie obronił Rzymu w 410 roku, jest rzeczywiście Bogiem potężnym? Mozaiki starają się to potwierdzić na różne sposoby. Bardziej wymowne są tu mozaiki z prawej strony nawy, pokazujące co chwila sceny bitewne, zwycięstwa Izraelitów i klęski ich przeciwników. Ale tak, jak pomyślność Rzymu opierała się na sile jego armii, tak Lud Boży opiera się raczej na pomocy Boga. Mozaiki wiernie oddają myśl teologiczną autorów biblijnych, piszących, że to „Jahwe walczy za Izraela” i „Pan Zastępów zdobywa Ziemię Obiecaną". Oglądamy w związku z tym wojska faraona tonące w Morzu 
Czerwonym, widzimy jak modlitwa Mojżesza pokonuje Amalekitów, jak Wódz Zastępów Niebieskich wprowadza Izraelitów do ziemi Kanaan (Joz 5,13-15), mury Jerycha walą się gdy Izraelici obchodzą je i dmą w trąby, jak deszcz kamieni (wysypywanych przez rękę wychylającą się z nieba) spada na Amorytów. Bóg nie tylko walczy za swój Lud, ale się też nim opiekuje - daje mannę i przepiórki, sprawia, że wody gorzkie stają się słodkimi (w obu tych scenach interwencja Boża jest pokazana explicite - Najwyższy unosi się na chmurze). Podczas buntu Izraelitów ręka Boska rozpościera wokół Mojżesza i jego dwóch towarzyszy mandorlę, od której odbijają się rzucane w nich kamienie.

Niektórzy uczeni starali się interpretować obie strony nawy w duchu znanego w piątym wieku dualizmu Ecclesia ex circumcisione i Ecclesia ex gentibus. Historie pierwszych patriarchów stanowiłyby więc ilustrację działania Bożej łaski per fidem sine lege, podczas gdy dzieje Mojżesza pokazywałyby tych, którzy secundum legem Moysi religiosam et piam militiam militabant ${ }^{20}$. Popiera się tę tezę podobną interpretacją łuku triumfalnego, gdzie na dole znajdujemy obrazy owiec wchodzących do symbolicznych miast: Jeruzalem (oznaczającego Ecclesia ex circumcisione) i Betlejem (oznaczającego Ecclesia ex gentibus). Równocześnie na samej górze łuku, po obu stronach pustego tronu, pokazani są apostołowie Piotr i Paweł, stanowiący również postaci symboliczne dla dwóch części Kościoła: z Żydów i z pogan. Ta interpretacja napotyka jednak jeden zasadniczy problem - Jerozolima i Piotr znajdują się po lewej stronie łuku, a więc po tej samej, od której wychodzi cykl Abrahama, Izaaka i Jakuba, podczas gdy Betlejem i Paweł są po stronie cyklu Mojżesza i Jozuego. Co więcej, wprawdzie jedna z mozaik po prawej stronie nawy przedstawia przekazanie Prawa przez Mojżesza (ponowne, przed jego śmiercią), ale nie ma już na przykład sceny odnowienia Przymierza nad Jordanem, natomiast po lewej stronie aż dwa panele poświęcone są związanej z obrzezaniem historii synów Jakuba i Sychemitów. Tak więc interpretacja podziału cyklu mozaik nawy według schematu ,wiara - Prawo" wydaje mi się wymuszona. Podział cyklu w sposób naturalny wynika z układu ksiąg biblijnych. Jeśli zaś chodzi o tematykę, właściwszym wydaje się podkreślenie ciągłości tematu wypełniania się obietnicy potomstwa po lewej i obietnicy ziemi po prawej stronie nawy.

Prawa strona nawy jest wypełniona scenami militarnymi, ilustrującymi opiekę Boga nad jego Ludem. Uwiecznianie zwycięstw nad wrogami miało w Rzymie długą i wspaniałą tradycję - wystarczy wspomnieć kolumny Trajana i Marka Aureliusza. Wchodzący do bazyliki Santa Maria Maggiore mieli więc widzieć, że Jozue to wódz porównywalny z rzymskimi bohaterami i cesarza- 
mi. Nie zapominajmy przy tym, że Jozue, przedstawiany według schematów ikonografii cesarskiej, jest równocześnie imiennikiem Jezusa i jednym z jego najważniejszych typów w Starym Testamencie - to on wprowadził Lud Boży do Ziemi Obietnicy, tak jak Jezus wprowadza Lud Boży do Królestwa Bożego.

Jak jednak tworzy się Lud Boży? Co decyduje o przynależności do niego? Odpowiedź dają sceny z lewej strony nawy: to wynik suwerennej decyzji i wyboru Boga. Łaski wybrania nie odziedziczy Ezaw - wybrany będzie młodszy Jakub, który z kolei za ukochaną żonę będzie miał Rachelę, a nie starszą Leę. Dzięki Bożemu błogosławieństwu i sprytowi Jakuba, w jego stadzie znajdzie się wiele owiec, mimo starań Labana, by do tego nie doszło. Owce są zresztą wszechobecne na mozaikach przedstawiających historię patriarchów, stanowiąc jakby zapowiedź owiec z łuku triumfalnego wchodzących do Jeruzalem i Betlejem, które z kolei symbolizują Lud Boży Nowego Przymierza, tworzony z Żydów i pogan.

Jaki był wzór, z którego korzystali twórcy mozaik w Santa Maria Maggiore? Zasadniczo uważa się, że ich dzieło było przeniesieniem na ściany bazyliki jakiegoś istniejącego już cyklu ilustracyjnego. Jednak jedynym odnalezionym analogicznym cyklem ściennym są freski z synagogi Dura Europos (wschodnia Syria). Podobieństwo z Santa Maria Maggiore jest tu jednak bardzo niewielkie, jeśli chodzi o dobór scen, i praktycznie żadne, jeśli chodzi o styl ${ }^{21}$. Styl mozaik z rzymskiej bazyliki jest za tu dużo bliższy współczesnym im kodeksom iluminowanym, takim jak Iliada Ambrozjańska, Vergilius Vaticanus i Itala Kwedlinburska ${ }^{22}$. Niektóre sceny wydają się być wzorowane na miniaturach ilustrujących kodeksy biblijne, późnostarożytne lub zachowane w średniowiecznych kopiach - bizantyński Oktateuch (Vat. Graec. 746), zwój Jozuego (Pal. Graec. 431 bis) ${ }^{23}$, Genesis Cottona z British Museum (Otho B. VI) ${ }^{24}$, Genesis Wiedeńska (ÖNB, Cod. Theol. XXXI) ${ }^{25}$. Niemniej jednak nie znamy żadnego kodeksu, który zawierałby taki wybór scen jak cykl z Santa Maria Maggiore. Jest prawdopo-

21 W synagodze w Dura Europos przedstawione są sceny z różnych ksiąg biblijnych, nie tylko z Pięcioksięgu, który reprezentowany jest przez sen Jakuba, Jakuba błogosławiącego Efraima i Manassesa, Jakuba błogosławiącego wszystkich swoich synów, dzieciństwo Mojżesza, powołanie Mojżesza, przejście przez Morze Czerwone, Mojżesza otrzymującego tablice Prawa, poświęcenie przybytku i studnię w Beer-Szebie. Zob. K. Wietzmann, The frescoes of the Dura synagogue and Christian art, Dumbarton Oaks 1990, 17-68.

22 J. G. Deckers, dz. cyt., 283-288.

23 F. Cabrol, H. Leclercq, Dictionnaire d'archéologie chrétienne et de liturgie, VII/2, Paris 1927, kol. 2683-2689.

24 F. Cabrol, H. Leclercq, Dictionnaire d’archéologie chrétienne et de liturgie, VI, Paris 1924, kol. 911-927. Ten kodeks jest wzorem mozaik w bazylice św. Marka w Wenecji

25 Tamże, kol. 927-939. 
dobnym, że taki kodeks istniał, lecz nie zachował się do naszych czasów. Można też przypuszczać że był to kodeks zawierający integralny tekst ksiąg biblijnych - ewentualność jakiegoś brewiarium odnosi się raczej tylko do historii Abrahama i Izaaka, dalszy ciąg zawiera już sceny zbyt szczegółowe i mało znane ${ }^{26}$.

Niezależnie od tego, jakie było dokładnie źródło, na którym opierali się twórcy mozaik w Santa Maria Maggiore, ich dzieło miało wielokrotnie większy zasięg oddziaływania niż pierwowzór. Mozaiki są co prawda umieszczone dość wysoko, a w niektórych scenach liczba i zagęszczenie postaci wyraźnie wskazuje na to, że pierwotny projekt był raczej przeznaczony dla miniatury, a nie obrazu ściennego, ale przy dobrym świetle słonecznym (lub zainstalowanej obecnie iluminacji elektrycznej) można wciąż śledzić przedstawione tam historie. Ten cykl to właściwie pierwsza znana nam Biblia pauperum - kodeksy były przecież dostępne tylko dla nielicznych wybrańców, podczas gdy do bazyliki mógł wejść każdy. Ukazane na ścianach Santa Maria Maggiore sceny z Sześcioksięgu stanowiły pewnie ilustrację do czytań liturgicznych i homilii, mogły też być zachętą dla tych, którzy potrafili czytać, by sięgnęli po Biblię i ujrzeli w niej korzenie swojej tożsamości. Lud rzymski, któremu Sykstus III dedykował bazylikę, miał w ten sposób zobaczyć, że jako Lud Boży posiadał w Starym Testamencie tradycję równie wspaniałą, chwalebną i interesującą, jak ta przekazana przez Wergiliusza i Tytusa Liwiusza.

\section{Summary}

The main nave of the Santa Maria Maggiore at Rome has been decorated with 42 mosaic panels, presenting the scenes from the Pentateuch and the Book of Josue. The mosaics were created at the time of the construction of the basilica in the first half of the fifth century and thus they are the oldest monumental Bible illustration cycle. Some illuminated codices probably served as a model for the mosaics, but the final result is rather an original conception, linked theologically with the mosaics of the triumphal arch of the basilica. The paper describes the surviving 27 mosaics. Their conformance to traditional Roman iconography is underlined. The main idea behind the cycle is interpreted as an attempt to convince the people of Rome that the history of the People of God, which begins with the patriarchs of the Old Testament, is as glorious and ancient as the Roman one.

26 V. Saxer, dz. cyt., 48. 